heartening words with which Mr. Roosevelt has encouraged the defenders of liberty and to the material aid which he has given, and in ever-increasing measure is giving, to secure the defeat of lawlessness and aggression among nations, and to the stand he is making for liberty, humanity and law. Mr. Roosevelt's message mentioned the historic precedent of this special Convocation, expressing his pleasure that it "does so in the great cause of preserving the free learning and civil liberties which have grown stone upon ston $\Theta$ in our lands". He concluded with the epigrammatic words: "We and all others who believe as we do would rather die on our feet than live on our knees."

\section{A Dynamic Civilization}

Is his presidential address "Industrial Progress, Whither and Why", before the Birmingham Metallurgical Society on March 8, Mr. C. H. H. Franklin pointed out that we are living in an epoch of dynamic change, and that whether we evolve into the finest civilization humanity has known or relapse into barbarism comparable with the Dark Ages of Europe after the fall of Roman civilization, is the principal issue. He urged that the future of industry, as of nations and of men, is being decided on the fundamental issues of free mutual co-operation, versus exploitation and compulsion. The organization of an animal or human structure provides valuable clues to the organization of our communal life, and he stressed the necessity of developing a team spirit in our industries and the concept of service of human and social needs if we are to extirpate the cancerous growth at present spreading in Europe and Asia and threatening all humanity. We need also to develop the technique of generating appropriate financial currents for human utility and service instead of its enslavement.

Mr. Franklin referred to the necessity of clarifying our concepts of the laws of growth, of change and of evolution, and of obtaining correct and not superficial answers to the questions of what we are making things for or why we are doing them in our present way. An individual or organization which reaches a stage where its sole concern is continuing its own existence is ripe for decay and dissolution. A great industrial city should display relies of its own industrial growth and models which show what has been and can be done. The deficiencies of past utensils have stimulated the desire and attempt to develop new materials which avoid these drawbacks. Referring to the new materials placed at our disposal by metallurgical progress, Mr. Franklin emphasized the importance of cooking utensils, and suggested that the most appropriate materials for such vessels are metals which, if attacked, only yield salts naturally present in the human body, or metals quite immune from attack. He also referred to the way in which care of cleansing should govern the choice of forms, and to the possible future of magnesium alloys in household tools. He looked forward to a world in which good things are efficiently prepared and craftsmen take a worthy place, the right properties being selected for a given purpose, and incorporated in worthy design, in which human personality or individuality is not cramped or repressed. By utilizing in this way for all our purposes the new resources at our disposal and working in this spirit of evolution, we can build up the harmony of life which our civilization is missing.

\section{The Position of the Jews}

IN his pamphlet "The Jewish Question" (Oxford Pamphlets on World Affairs, No. 45. Oxford : Clarendon Press. $3 d$. net) Mr. J. Parkes points out that the Jewish problem arises from two sources: the Jewish tradition, which has inculcated in Jews the need to keep themselves separate if they would survive as Jews, and Jewish experience at the hands of the peoples among whom they have lived. Mr. Parkes shows how Jewry has been unfairly identified with all the malpractices of modern commerce and industry and the way in which prejudice, by embittering Jewish experience, has accentuated the minority problem which Jewry might normally present. Modern anti-Semitism has made the problem acute through two main factors: the persecutions in Tsarist Russia at the end of the nineteenth century, which led to the flooding of Western Europe and America with several million Jewish refugees from a totally different level of culture; and the fever of nationalism which spread over the world after the War of 1914-18 and made life difficult for all minorities.

Mr. Parkes considers that the accurate and scientific studies of the question we possess, and our knowledge of the effects of past experience, warrant the view that with planning and co-operation there is nothing in the Jewish problem which need cause pessimism or despair. He suggests that in the light of experience of the last twenty years, a minority is entitled to a communal organization, recognized as a public body, and with control over primary education and teachers' colleges, charitable foundations, and cultural activities, as well as to religious freedom and authority in religious matters where the minority is also a religious minority. On each point the majority has certain rights, for example, in regard to language. Among the Jews themselves, assimilation with their countries of adoption, or the foundation of a Jewish national home have been the main programmes proposed and followed. The basic problem confronting Jews lies in the view which they take of their status: whether they wish to be considered merely a religious minority or a separate national minority. The ultimate problem of Jewry is the rediscovery and reassertion of the fundamental spiritual and social realities of Judaism, to which both assimilation and Zionism are capable of offering soils already prepared.

\section{Bread Flour}

Prof. J. ReIlly, professor of chemistry in the National University of Ireland (University College, Cork), has produced a booklet entitled "Our Daily Bread" which is particularly interesting at the present 
time in view of the desirability of making the British Isles less dependent on imports of wheat for its 'daily bread' (Cork : Forum Press. 2s.). He advocates the increased growing of rye, which is hardier than wheat and can be grown on poorer soils, and points out also that oaten and barley flour may without any dietetic disadvantage be used to eke out supplies of wheat. Growers of potatoes should be encouraged to set aside a portion of the crop for the production of potato flour, which is able to furnish us with our carbohydrate needs. It is interesting to note that flour was so scarce in England in 1800 that the Brown Bread Act was passed forbidding the use of pure white wheaten bread, and at this time flour was generally a mixture of equal parts of wheaten and rye flour. Wholemeal bread, of course, in contrast to white bread, contains comparatively large amounts of vitamins and minerals, although this is not the whole of the story.

\section{Origin of Cultivated Water-Melons}

Accordrng to Dr. Orland E. White of the University of Virginia, Africa, not America, is the native land of the water-melon. Speaking before the meeting of the Virginia Academy of Science, he told of recent researches at the Blandy Experimental Farm, which throw new light on the ancestry of this plant. Water-melons were not known at either the Epicurean feasts of ancient Greece or the Lucullan banquets of Rome. Not until the great age of exploration in the sixteenth century do they appear in the world picture. Dr. White is of the opinion that the Portuguese, pushing southward along the coast of Africa, became acquainted with the ancestors of modern water-melons growing wild in South Africa. They soon transferred them to their colony of Brazil, where the Indians promptly adopted them and added them to their own array of crops. Thus the myth of an American origin of water-melons came into being.

Dr. White has obtained seeds of several strains of these small wild South African melons, which have little enough resemblance to the monsters of the modern melon patch. He also has under cultivation stocks of a bitter variety of melon, known as the colocynth, familiar to the ancient Egyptians and other Mediterranean peoples, but used by them only as medicine. He has made many crossings between them and modern cultivated water-melons, some of which may eventually prove commercially valuable.

\section{Phenology of 1940}

With commendable promptness, the fiftieth Phenological Report of the Royal Meteorological Society, covering 1940, has just been issued despite war-time difficulties making it impossible for the executive committee to meet since the last report. With the exception of a small amount of introductory text, the report consists of a series of tables and diagrams, as has been its increasing trend in recent years. It has the observations of 288 phenological observers in the British Isles, compared with 385 in 1939. The publication of full moteorological details is still restricted, but it includes the events of the historic cold spell early in 1940, probably the coldest January for a hundred years and the sunniest for fifty years. The marked lateness of plants and insects caused by the cold opening of the year gave place to considerable earliness which mainly persisted from the end of April, with a succession of warm, mild spells, and the beauty of spring and early summer was enhanced by the simultaneous occurrence of normally early species which had been retarded and the normally later species which were brought forward.

This recovery also applied to crops, although some autumn-sown cereals failed to survive the winter. The droughty conditions in May, June, and, after a cool showery July, again in August and early September, had an interesting effect upon the grass; in the north-west the assessed condition remained between 77 and 78 per cent throughout August, whereas in the south-east it deteriorated from about 77 per cent to about 56 per cent, during which period the rainfall was about 30 per cent of the average in the north-west but only 3 per cent in the south-east. Indigenous insects are unlikely to have been affected so much as indigenous birds, which, however, had a favourable nesting season after so hard a winter. Migrants arrived at dates not far from average in the south but somewhat later in the north, while the only large-scale insect immigration was that of the large white butterfly (Pieris brassicae). The comparative earliness of the north-west district is shown in the plant and insect diagrams, in advance of the south-east up to May.

\section{Design of Wire Networks Carrying Radio Programmes}

In the Bell Laboratories Record of April there is an instructive paper by A. E. Bachelet explaining some of the difficulties encountered when designing wire networks over which radio programmes are transmitted. These in America often form extensive systems with broadcast stations or studios in most of the larger systems interconnected by high-quality crreuits employing amplifiers. The transmission over these circuits differs from ordinary telephone transmission in that it is unidirectional, and one-way amplifiers are employed. Since a studio may either transmit or receive programmes, it is necessary to provide means for changing the direction of transmission over the network. In the past this has been done either by using separate facilities which transmit in opposite directions, or by interchanging the input and the output of the amplifiers by the use of switches manually operated.

To provide quicker reversals, a remotely controlled reversing circuit has been developed which permits the reversal of the circuits to be controlled from the studio originating the programme. Reversals are effected by relays, controlled by direct current transmitted over the two conductors of the programme circuit, and returned through the earth. Any studio may assume control and set up the network so as to transmit the programme from it to the other points on the network. As long as this studio 